\title{
NARASI TENTANG AUTISM DI FACEBOOK (Studi Autoetnografi pada Status K.W)
}

\author{
Frida Kusumastuti, Jeanne Leonardo, dan Radityo Widiatmojo \\ frida@umm.ac.id \\ Program Studi Ilmu Komunikasi Universitas Muhammadiyah Malang
}

\begin{tabular}{l} 
Article Info \\
\hline Keyword: \\
Narasi, Autism, Kecacatan, Face- \\
book.
\end{tabular}

\begin{abstract}
The narrative of a mother who is directly involved in living with a child with an autistic child's lifetime is worth noting because it can complement the narrative of the Professionals (doctors, psychiatrists, psychologists, educators). Especially if the narrative is done openly on social media such as Facebook. Social Media gives the opportunity of public voices that were originally being repossessed by large narratives. Thus the purpose of this research is to interpret the narrative of the subject about autism based on daily experience (everyday life). Narrative is the way someone tells his experience. The narrative about Autism, commonly referred to as "disability", is not necessarily the same as the people's narration or family. The narrative of experts and the general public about defects is often done in a dichotomistic, i.e. only when defects - including autism - are seen as sadness or suffering, and when a defective individual is successful with extraordinary achievement. This research was conducted on a Facebook social account, which is a KW account - a single-parent mother claiming to have five children, of which three of them (15 years old, 10 years old and 7 years old) were autistic. The choice on the subject of the study because the KW handled the children's autism with a full involvement with no shadower nor professional caregiver. Secondly, $K W$ is capable of conducting autism narrative through social media (Facebook) which is open. The results showed (1) Narrative about the nature, attitudes, and principles of Autism, (2) narrative on the achievement of autism.
\end{abstract}

Copyright (C 2019 Interaksi: Jurnal Ilmu Komunikasi. All rights reserved.

\section{PENDAHULUAN}

Suatu "kecacatan" seringkali mendapatkan stigma di masyarakat. Seperti ditulis Mubarok (2012) bahwa kelompok tertentu seringkali mendapatkan stigma jenis blemishes of individual character. Misal, pada mereka yang memiliki karakter tercela. Juga mereka yang memiliki ketimpangan karakter seperti gangguan mental, gila, dan keterbelakangan mental. Begitupula dengan autism sebagai salah satu gangguan perkembangan anak.

Definisi tentang autism dan pemahaman akan autism akan mempengaruhi cara orang-orang menangani autism. Jika dilihat dari sejarah, awalnya gangguan autism ditemukan di dunia kedokteran tahun 1908-1911. Seorang psikiater, Eugene Bleuker mengamati adanya suatu ciri tertentu pada penderita skizofrenia dewasa yang ia sebut sebagai autism. Maka di awal definisi tersebut, penanganan autism disamakan dengan penanganan gangguan jiwa oleh psikiater. Namun ketika pada tahun 1944 diketahui bahwa autism merupakan gangguan perkembangan, maka penanganan anak penyandang autis juga dilakukan oleh dokter tumbuh kembang atau dokter anak.

Amerika Serikat menetapkan Buku Diagnostics and Statistics Manual of Mental Disorder (DSM) sebagai pedoman standar diagnosis autism di Amerika Serikat. Sejak ditetapkan pada tahun 1952 (DSM I). Buku tersebut diperbaiki terus menerus sejalan dengan perkembangan riset tentang autism. Hingga sekarang yang digunakan adalah DSM V yang diterbitkan pada tahun 2013, melebur semua istilah yang berhubungan dengan autism menjadi satu kesatuan yang disebut sebagai Autistic Spektrum Disorder (ASD). Gangguan 
Spektrum Autism merupakan suatu gangguan perkembangan yang perlu mendapat perhatian yang serius, bukan hanya karena gangguan fungsi adaptif anak namun juga dapat mempengaruhi kehidupan keluarga secara keseluruhan (Wiguna, 2015).

$$
\text { Melihat sejarah perkembangan }
$$

ditemukannya autism, diagnosis, dan tata laksananya, nampak bahwa sebelumnya narasi tentang autism masihlah terbatas dilakukan oleh para profesional. Namun, dewasa ini di era digital khususnya di era social media, penyandang autism dan juga keluarganya mulai mendapat peluang melakukan narasi tentang autism. Munculnya online parent support group seperti LRD, Putera Kembara, Orang Tua anak ABK, nampak memiliki anggota yang sangat banyak. Bahkan LRD misalnya telah memiliki 10 ribu lebih anggota. Dan juga ada grup khusus LRD Tennager and Adult. Para anggota online support group tersebut secara intens menceritakan pengalaman masing-masing, dan juga berbagi serta mendiskusikan apa yang mereka alami bersama. Khusus kasus di Indonesia, sejauh ini penelitian dengan topik narasi penyandang autisme maupun narasi orang tua tentang anaknya yang menyandang autism, belum peneliti temukan. Salah satu penelitian yang menjadikan kaum difable sebagai subjek, misalnya yang dilakukan oleh A. Susilo (2017), Tetapi itu adalah narasi para penyandang tuna rungu tentang komunikasi mereka. Oleh karena itu masih diperlukan lebih banyak penelitian dan narasi tentang autism di ranah-ranah publik.

Era digital telah memberi peluang bertemunya narasi para profesional dengan narasi para penyandang autisme, maupun narasi orang-orang yang hidup bersama penyandang autis. Beragam jurnal dan hasil penelitian dideseminasikan dalam bentuk artikel jurnal. Namun ranah tersebut hanya bisa diakses oleh kalangan tertentu saja.

Ranah yang lebih cair adalah ranah dimana semua orang bisa berintekasi dengan bantuan teknologi. Facebook adalah salah satu ranah tersebut. Dunbar dan Conti dalam bukunya berjudul Online Social Network, menyatakan bahwa facebook merupakan jejaring sosial yang paling banyak digunakan oleh manusia diberbagai belahan dunia (2015). Di Indonesia, penetrasi facebook menjadi nomor satu karena turut didukung oleh kehadiran smartphone, dimana dari 77 juta pengguna facebook, 61 juta diantara menggunakan smartphone untuk mengakses facebook.

Ini merupakan bonus demografis yang bisa menjadi dua bilah pisau. Akan sangat tumpul ketika kemampuan literasi digital masyarakat masih rendah ataupun akan sangat tajam ketika informasi dan narasi yang ada diproduksi dengan baik.

Dengan jumlah pengguna terbesar, maka peluang untuk menyampaikan narasi juga besar adanya. Narasi autism yang diproduksi oleh kalangan profesional tidaklah cukup menyentuh level grassroot dari pengguna facebook. Maka narasi yang dibangun oleh individu justru memiliki daya yang mampu menyentuh ruang-ruang privasi, seperti komunitas atau kelompok tertentu.

Narasi sejatinya merupakan cara seseorang menceritakan pengalamannya. Block dan Weatherford (2013) memaparkan bahwa secara filosofis salah satu fungsi naratif adalah menjelaskan realitas subjek dan mendefinisikan berbagai tanda atau kode yang menghubungkan manusia menjadi sebuah komunitas yang utuh. Eksistensi penyandang autism dan sekaligus eksistensi keluarga yang hidup dengan penyandang autis adalah bagian kelompok dari masyarakat yang besar. Keberadaan mereka dari tahun ke tahun bertambah. Jumlah ini tidak bisa diabaikan. Masyarakat perlu memahami lebih menyeluruh tentang kehidupan penyandang autism. Narasi orang tua bisa menjadi unit analisis manakala anak-anak penyandang autis belum mampu mengungkapkan pengalamannya karena alasan tertentu. Misal, kemampuan verbal yang belum baik, atau juga karena kemampuan sosial yang belum memungkinkan terjadinya interaksi antara peneliti dan para penyandang autism. Narasi orang tua perlu diekplorasi untuk mendapatkan gambaran kondisi dan eksistensi autism, sesuai pengalaman aktual dan keterlibatan mereka dengan penyandang autis dalam kehidupan sehari-hari. (Rogers dkk., 2012; Kin dkk., 2014; Lázaro and Pondé, 2017; Kusumastuti, 2018), dan inilah yang menjadi kebaruan yang ditawarkan oleh riset ini. 
Tulisan ini merupakan hasil riset naratif tentang apa saja narasi autism berdasarkan konstruksi orang tua yang hidup bersama anak autism, dengan tujuan penelitian untuk mendeskripsikan narasi tentang autism di facebook berdasarkan konstruksi orang tua yang hidup bersama anak autism.

\section{KAJIAN PUSTAKA}

Metodologi

Menurut Nollaig Frost, sejarah riset naratif dibagi menjadi dua tradisi utama. Pertama, personcentered, yang menempatkan pencerita dan pendengar sebagai satu kesatuan utuh. Pendekatan humanis ini fokus pada biografi individu dan cerita kehidupan. Sedangkan tradisi kedua adalah multi-subject dalam struktur naratif, yang lebih terkonsentrasi pada produksi makna dalam sebuah narasi, baik makna yang disadari ataupun makna yang tidak disadari. Tradisi ini juga memberikan perhatian khusus pada kondisi sosial dan faktor relasi-kuasa yang mempu mempertajam sebuah narasi (2011).

Berdasarkan tradisi inilah, definisi naratif sangat beragam. Namun setidaknya Frost mendefinisikan naratif sebagai sebuah satu kesatuan cerita yang utuh dan urut, yang disampaikan kepada khalayak tertentu dengan cara yang bermakna (2011). Definisi ini mengakomodir kedua tradisi. Secara lebih spesifik, Gockel menambahkan bahwa naratif sangat berafiliasi dengan "pengalaman", karena integrasi antara cerita, nalar, dan aspek sosio kultural sangat bergantung pada pengalaman sang pencerita (2013). Penelitian Rachel Dwyer juga menyatakan bahwa pengalaman turut membawa manusia ke dalam skala narasi yang lebih besar (2017).

Riset naratif bersifat kualitatif dan sangat bergantung pada bagaimana sebuah narasi dikonstruksi, diterima, disamarkan ataupun ditolak oleh manusia. Hal inilah yang menyebabkan riset naratif memiliki fleksibilitas dalam hal titik awal dan titik akhir, atau yang oleh Andrews, Squire dan Tamboukou sebut sebagai finishing point (2008).

Terdapat beberapa metode yang digunakan un- tuk melakukan riset naratif. Block dan Weatherford mengembangkan empat metode utama. Pertama, berkisah secara realis, atau yang disebut sebagai Realist Tales (2013:503). Metode ini berusaha mendekatkan peneliti dan subjek dengan konstruksi cerita dan konstruksi data sesuai masing-masing pengalaman. Tujuan utamanya adalah memperoleh rekonstruksi subjek dan mengekstrak identitas diri secara emosional. Kedua, autoetnografi, yaitu narasi tentang diri sendiri. Dengan eksplorasi diri, subjek diharapkan mampu mengetahui kualitas dirinya secara subjektif. Cara paling mudah adalah dengan menganalisis "catatan harian" subjek. Ketiga, puisi. Teknik ini adalah aktualisasi diri melalui rangkaian kata-kata. Emosi akan disalurkan melalui kata-kata yang kehesif dan koheren. Block dan Weatherford menggarisbawahi bahwa kata-kata berperan penting dalam menarasikan diri atau kondisi sosial (2013:508). Keempat, fictional representation. Metode ini menggunakan pendekatan antropologis untuk menyamarkan identitas subjek dalam sebuah kelompok, sehingga subjek bisa mengeluarkan aspek emosional dari pengalaman personal.

Untuk melakukan analisis naratif, Frost membaginya dalam empat tahapan kerangka kerja (2011). Pertama, menentukan pendekatan epistimologis. Hal ini penting dilakukan untuk memperkuat pijakan paradigma peneliti, yaitu konstruktifis atau naturalis. Kedua, menentukan model analisis yang akan digunakan. Model struktural menempatkan subjek sebagai teks yang merepresentasikan narasi yang dibangun berdasarkan pengalaman hidup subjek. Model ini fokus pada bagaimana sebuah narasi dikonstruksi sesuai dengan masanya. Model berikutnya adalah model tematik, yang lebih fokus pada konten dari narasi itu sendiri. Model ini bisa diaplikasikan pada berbagai narasi yang bersifat teks verbal dan teks non-verbal. Model terakhir adalah model interaksional-performatif, dimana narrator dan pendengar berkolarasi untuk menghasilkan dan mengkonstruksi makna. Model ini bergantung pada diskursif konteks, kondisi sosio-kultural, historisitas serta interaksi manusia. Menurut Frost, model ini sangat cocok dengan studi komunikasi khususnya pada konstruksi identitas manusia (2011).

Ketiga, melakukan seleksi narasi yang akan di- 
analisis. Luaran dari tahap ini adalah segmen data, sehingga perlu dilakukan pemilahan data-data agar memunculkan hasil analisis yang lebih tajam. Keempat, adalah tahapan analisis. Peneliti bisa menggunakan struktur analisis yang sesuai dengan pertanyaan penelitian.

Berdasarkan pemaparan diatas, riset naratif ini menggunakan metode Autoetnografi dengan pendekatan kuantitatif, dengan K.W sebagai subjek penelitian. Langkah-langkah penelitiannya, pertama peneliti memilih status subjek di facebook yang menggambarkan pandangannya tentang autism berdasarkan pengalaman aktual dengan sang anak. Kemudian peneliti melakukan pengelompokan isi status berdasarkan topik-topik yang muncul. Peneliti menghubungkan status demi status subjek yang satu kelompok topik. Termasuk balasan subjek atas komentar-komentar para pembacanya. Dan begitu seterusya sehingga peneliti mendapatkan narasi subjek yang utuh untuk setiap topik tentang autism.

\section{Subjek Penelitian}

K.W adalah wanita berusia 41 tahun, kelahiran Jakarta. Ayah K.W berasal dari suku Jawa sedangkan ibunya etnis tionghoa asal Bandung. Sejak lahir hingga usia sekolah menangah atas, K.W tinggal bersama orang tuanya di Jakarta. Setelah lulus SMA, K.W sempat kuliah di Kota Malang, namun tidak sampai lulus. Sempat juga mengikuti TAPE atau kursus di Monash Melbourne Australia.

Pada tahun 1998, K.W menikah dengan seorang pria keturunan Arab WN Malaysia. Namun pernikahannya kandas pada tahun 2011 lalu karena kasus Kekerasan dalam Rumah Tangga (KDRT). K.W akhirnya sebagai single parent dan tinggal dengan lima anak. Tiga diantara anaknya adalah lelaki: BL (19), JH (17), MU (14), dan dua yang lain perempuan AI (9), HU (7). Diantara kelima anaknya, tiga anak terakhir berkebutuhan khusus. MU didiagnosis autis, dyslexia. AI dinyatakan Attention Deficit Hyperactivity Disorder (ADHD), pica, sensory problem, dan HU dinyatakan ADHD.

Akun Karinda menarik diteliti karena produktifnya dalam mengunggah status dan juga beberapa status menunjukkan kemampuan membangun diskusi publik diantara jaringan pertemanan di facebook. Keaktifan subjek penelitian dalam mengunggah status di facebook sangat mencukupi untuk penelitian narative. Selain itu peneliti tertarik karena status Karinda juga menunjukkan upaya literasi tentang dunia anak berkebutuhan khusus. Terutama anak autis, down syndrome, dan retradasi mental. Berikut temuan-temuan penelitian.

Pada tahun 2014 peneliti melihat Karinda jarang menulis status di Grup ABK. Namun, dia sangat produktif unggah status di akun pribadinya. Rupanya Karinda lebih nyaman berpendapat di beranda pribadi daripada di beranda Group yang juga beranggotakan para pakar (dokter, psikiater, psikolog, therapist, guru). Karinda memilih menjadi pembaca saja dan hanya sesekali mengomentari diskusi. Salah satu pengakuannya adalah dia tidak mengikuti "mainstream" di grup yang sangat tidak merekomendasikan anak di beri obatobatan. Sementara anak-anak Karinda mengikuti prosedur kesehatan di Malaysia, malah diberi obat jika tantrum berlebihan dan mengalami social anxiety karena keperluan khususnya. Sejak itu peneliti semakin tertarik untuk mengamati pengalaman hidup Karinda dalam mendampingi anak-anaknya yang berkebutuhan khusus. Tidak hanya tentang cara dia, melainkan juga bagaimana Karinda mengomunikasikan pengalamannya melalui status-status di akun facebooknya.

Akun K.W menarik diteliti karena produktifitasnya dalam mengunggah status dan juga beberapa status menunjukkan kemampuan membangun diskusi publik diantara jaringan pertemanan di facebook. Peneliti tertarik karena status K.W juga menunjukkan upaya literasi tentang bagaimana hidup bersama anak berkebutuhan khusus. Terutama anak autis, down syndrome, dan retradasi mental.

\section{Kajian Konseptual}

Facebook membuat pengalaman sosial mudah diakses seperti layaknya membaca sebuah buku harian, dengan tersedianya struktur dan konfigurasi yang memungkinkan dibaca oleh jaringan sosial masingmasing penggunanya (Katie 2012).

Dengan adanya facebook sebagai pengganti buku harian, manusia merupakan pemilik artefak-artefak yang diciptakannya dalam kurun waktu tertentu dan fragmen 
-fragmen tersebut bentuk dari representasi diri manusia itu sendiri. Dengan kata lain, facebook adalah wadah, tempat atau rumah bagi narasi-narasi individu diberbagai belahan dunia. Sebagai media yang memuat konten sejarah, budaya dan sosial ekonomi, Facebook telah menjadi sebuah perilaku kesadaran sosial akan masa lalu dan masa sekarang (Katie 2012).

Ketika facebook sudah membumi, Alex Lambert menyebutkan bahwa keintiman atau kedekatan merupakan konsep yang krusial di dalam sosial media dalam membentuk struktur perilaku publik (2015).

Hal inilah yang membuat penulis yakin bahwa status-status yang dituliskan di dinding atau wall facebook merupakan catatan harian yang menarasikan lifeworld dari masing-masing penggunanya.

Aspek interaktifitasnya pula yang turut membantu sebuah narasi bisa ditelusuri, dimaknai, serta diartikulasi secara komprehensif, karena didalam percakapan di sebuah status facebook mampu menarik orang lain untuk turut berkomentar, menyanggah ataupun mengapresiasi. Sifat inilah yang tidak ditemukan dalam catatan harian konvensional.

\section{HASIL dan TEMUAN}

\section{Sifat, Watak, dan Prinsip Anak Autis}

Beberapa status K.W menceritakan sifat, watak, dan prinsip anak-anak autis. Seperti pada status 31 Maret 2018 yang menceritakan bagaimana MU memiliki sikap terpuji dalam menyayangi anjing. Bagi MU anjing adalah ciptaan Allah yang juga harus diberi kasih sayang oleh manusia. Bahkan dalam status tersebut, K.W memberikan kritikan pada sebagian orang yang memahami anjing sebagai binatang yang najis, sehingga harus dimusuhi. Sementara K.W melihat prinsip MU tentang makna najis untuk liur anjing itu mudah saja menghilangkannya dengan dibasuh menggunakan tanah, lalu air sesuai dengan tuntunan Nabi Muhammad SAW.

Anjing itu memang najis air liurnya..tapi najis bisa dibersihkan...Mubarak itu suka banget menyisihkan duitnya untuk membeli makanan dikasih ke anjing liar..bahkan pernah dia lari ke tengah jalan untuk bopong anjing sekarat yang ketabrak kendaraan...saya nggak melarang dia karena dia punya jiwa kasih saying sama mahluk ciptaan allah...

Suka nggak paham sama orang yang benci sama anjing dengan alasan agama.. bukannya islam itu agama penuh kasih saying tapi kamu apa nggak malu malah pamer kebencian terhadap binatang nggak berdosa? (status tanggal 31 Maret 2018)

Karakter MU juga dikonstruksi oleh K.W sebagai pribadi yang penuh dengan rencana dan pandangan yang futuristik. Seperti nampak pada status 21 Maret 2018. Pada status tersebut, K.W menyempatkan mengutarakan respon dia atas rencana MU. Yaitu tidak langsung memberi janji, sebab bagi anak autis yang menurut K.W cenderung "lempeng" maka begitu diberi janji, mereka akan menagih terus menerus untuk ditepati.

Berkaitan dengan prinsip atau kepribadian anakanak, status K.W menunjukkan bahwa kehidupan spiritual anak-anak luar biasa. Sami'na wa Ato'na. Seperti status berikut ini yang dunggah 9 Februari 2018. Terhadap spiritualitas HU, K.W sering dibuat tidak terduga. Konsep ajaran agama Islam benar-benar HU telan dengan "kaffah" dan ditelan mentah. Oleh karena itu K.W mendudukkan pelajaran agama sangat penting untuk anak-anak. nasihat kebajikan, dan soal ibadah bisa anak autis terima dengan baik dan diamalkan secara nyata.

Pada beberapa status, K.W menggambarkan MU sebagai lelaki yang bertanggung jawab, penuh kasih sayang, serta bertaqwa.

den mas ngabehi mumu ngumpet dikamar..gelap-gelapan.. dia stress ..ada cewek cantik dari sekolah swasta ngajuin diri untuk jadi pacarnya den mas ngabehi ..mamas ngabehi udah bilang dia nggak mau pacarana..tapi cewek itu bilang ..tak pe awak tak nak sekarang saya akan tunggu awak...gubrak... sekarang seweknya ada diluar rumah..ngapelin mumu dan mumunya nggak mau keluar..emaknya bingung..ini cewek bela belain naik grab loh.. jauh dari matrix inter- 
nasionalschool di bandar baru seri sendayan

sama... (status tanggal 28 Maret 2018)

Kepribadian anak autis khususnya AI diungkapkan oleh K.W pada status tanggal 19 Maret. Sikap kritis, terus terang, namun juga mudah diberi pengertian atau pemahaman menjadi ciri khas AI yang mild autis dan Asperger.

Aisyah"mii susu tu mahal ke? mi tak mampu beli susu ke? yang susu lembu (sapi)"

dia nyodorin duit rm 10 "aisyah ada duit mam alya bagi..mi gunalah beli susu..aisyah terasa nak merasa susu”

saya mewek.."bukan sebab tak mampu syah..tapi aisyah kan diet casein...casein itu salah satunya ada dalam susu lembu,,aisyah kan ada aspeger jadi kena die casein tu”

aisyah "kenapa aisyah kena diet mi? kenapa orang lain boleh makan minum tak de pantang larang...kenapa allah bagi aisyah ada aspeger $m i ?$

saya mewek maning "sebab allah saying aisyah..allah menjadikan semua ciptanya berbeza antara satu dengan lainnya..setiap mahluk ada ke istimewaan..allah beri aisyah ke istimewaan jadikan aisyah aspeger..kenapa aisyah kena diet..sebab nakjadikan aisyah lebih baik.lebih focus..lebih elok.. ada manusia yang tak dapat tolerate makanan tertentu syah..makanan akan jadi racun untuk badan dia sebab reaksi dalam sistem badan..contoh orang alergic dengan kacang..bila makan kacang akan jadi sakit..allah bukan nak dera syah..allah saying sebab tu allah nak kita kendalikan diri dari hawa nafsu..manusia beriman berjihad dengan mengendalikan hawa nafsu..untuk aisyah jihad aisyah adalah menahan diri tak consume casein macam susu lembu...tak consume gluten..allah nak bagi aisyah kumpul banyak pahala berjihad.."

aisyah "kan aisyah dah ada mas jihad jihad" saya "itu lain lah.."

aisyah "aisyah paham..allah nak aisyah kum- pul banyak pahala ye mi.."

saya peluk dia

kok saya jadi ndlewer maning (Status tanggal 19 Maret 2018)

Beberapa kali memang K.W menggambarkan AI sebagai anak "gadis" yang feminin, sentimental (halus perasaan) dan memiliki sense of art/aestetic.

Pagi-pagi husna ngasih mamaknya duit rm10..

Saya "duit apa nas?”

Husna "mama kawan nas bagi dekat sekolah..sebab nas tolong kawan nas bersihkan baju sebab kena muntah ditandas (toilet) dia tak sihat ami..kasian muntah teruk (parah) nas tolong dia bersihkan baju yang kena..nas bagi tau ustazah engku sebab cik gu Khairul tak de"

Saya terharu "masya allah anak mami solehah baik hatinya"

Husna "kan kite kena saying menyayangi... mama dia datang mam dia bagi unas duit.tapi unas tak suka duit merah tu rm10 banyak sangatlah..patut bagi duti biru rm 1 sudahlah..kanak-kanak tak elok pegang duit banyak.nanti kena culik, tu yang unas bagi dekat ami..nanti duit tub oleh ami guna"

Saya terharu "jadi ami boleh pakai dui tunas?"

Husna "yelah ami pakailah dui tunas tu..kan nanti kedai ami pakai duit tu belikan unas pokeball dengan dolls yaaa..kalau tak cukup ami simpan dulu..nanti ami tambahkan duit ami biar cukup beli pokeball dengan dolls baby..nas nak dolls baby"

Haseem...ujung-ujungnya kok gini... (Status tanggal 27 Februari 2018)

Status yang diunggah 27 Februari 2018 menggambarkan perilaku HU yang penolong, perhatian pada sesama, jujur, sederhana, dan juga cerdik. Tipe tersebut mirip dengan tipe MU. Jika melihat status-status K.W tentang MU dan HU, mereka digambarkan sebagai pribadi-pribadi yang pandai berkawan, setia pada kawan, dan perhatian. 
K.W menceritakan salah satu sifat, watak, dan prinsip anak autis adalah melihat kebenaran dan yang tidak benar sebagai dua kutub hitam dan putih. Anak autis sering tidak bisa memisahkan realitas sosial dengan realitas fiktif. Seperti nampak pada unggahan status 19 Maret 2018. K.W menceritakan betapa AI cenderung menerima mentah-mentah apa yang dia dengar, dia lihat, dan akan diingat sebagai kebenaran. Status 19 Februari 2018 juga menunjukkan bahwa khas AI dan juga MU adalah sering menghubungkan realitas psikologi dan realitas sosial yang campur baur.

Aisyah kecewa banget dikasih tau beauty and the beast nggak beredar dimalaysia..tadi nonton versi kartunnya didisney channel ngobatin kecewanya

Aisyah "patutlah yang jahat ni gaston ya"

Saya "kenapa syah?”

Aisyah "iyelaah jupe pun dia tinggalkan macam tu je walau jupe ni setia..ni kat sini dia nak kan belle juga..fitnah ayah belle"

Saya kaget kok dia tau masalah jupe darimana sih

Saya "aisyah tau darimana jupe gaston?"

Aisyah "mamk devin cerita dengan mbak mbak kerja kilang",

Awas kamu mamaknya devin tak cubit kamuuuu..asiyah jadi nyangka gaston mantan jupe sama kayak gaston di beauty and the beast (Status tanggal 19 Maret 2018)

Prestasi dan Pencapaian Anak Autis

Status-status K.W banyak bercerita dengan penuh rasa syukur tentang pencapaian prestasi anakanak, terutama MU dan AI. Jika MU dinilai berbakat pada masak memasak, namun bercita-cita menjadi atlet. Sementara AI berbakat di seni terutama seni fashion dan modeling. Seperti diunggah pada status 27 Februari 2018 berikut ini:

Alhamdulillah mumu lolos kualifikasi pertama pembinaan jadi atlet paralimpik daerah sepang..untuk tolak peluru dan lempar cakram..tinggal nunggu untuk archery alias memanah sama bowling.. jadwal mumu ngabehi de caprio padat mulai bulan depan.. rabukamis ikut jamboree pengakap alias boy scout daerah sepang.. tanggal 5 kualifikasi bowling..tanggal 8-12 full kompetisi lempar cakram dan tolak peluru..belum praktek dapur dan kebun lagi.. mugi-mugi gusti allah paring mamaknyasehat ya lee.. biar bisa jadi city hunter. hunter sana sini..

Aisyah juga jadwalnya penuh..latihan nari..persiapan jamboree daan latihan buat percobaan marathon.. ditambah nunggu jawaban permohonan untuk ikut les dasar sign language dari persatuan bisu pekak malaysia..

siapa bilang anak disabilitas autis adhd dan dyslexia nggak bisa bermanfaat nggak bisa selayaknya kalian yang normal..berarti kalian kurang semarr eeh kurang smart..perlu banyak jalan jalan hokiday ehh holiday (status tanggal 27 Februari 2018)

Selain HU, status K.W juga menceritakan prestasi AI. Meskipun AI juga dilihat K.W berbakat pada modeling, dan fashion, rupanya K.W mampu menyalurkan energi AI yang super ke cabang olah raga. Berikut statusnya tertanggal 17 dan 24 Januari 2018. Kebanggaan K.W pada MU juga nampak pada statusstatusnya. Prestasi Sosial MU di sekolah, keterampilan MU memasak, dan kepribadian yang baik menjadi poin dalam status K.W. Seperti status berikut ini.

Mubarak terpilih jadi team leader proyek bakery dan pastry di sekolah...hasilnya untuk nambah dana kegiatan praktek kemahiran hidup sekolah..kalau ibu Primaningrum Arinarresmi liat sendiri presentasi mamas ngabehi pas ditanya kenapa harus dia yang jadi leader... pasti hati ibu berkembang Bahagia tanpa perlu pake yeast dan baking powder jawaban Mubarak karena saya ada semangat dan sifat kepemimpinan. dan saya mencotoh beautiful ibu mima di Indonesia sana yang pandai buat macam macam pastrt dan roti..ibu adalah idola saya..plastic bungkus roti pun sudah sedap..apalagi rotinya.. (Status tanggal 8 januari 2018) 
Cara berpikir HU mendapat perhatian tersendiri dalam status-status K.W. Selain lempeng alias lurus, out of the box, dan suka menghubungkan realitas pikiran dan realitas empiris.

Status 24 Februari 2018 di atas menggambarkan suasana batin AI yang memiliki sense untuk memberi kado Ulang Tahun uminya (K.W). Bagi seseorang dengan kebutuhan khusus, bisa memiliki perasaan sedemikian tentu luar biasa. Walau juga dengan cara yang "luar biasa."

K.W pernah mengunggah status yang menggambarkan kepekaan anak-anaknya akan "rasa dosa" dan tanggung jawab tidak membuat umminya kecewa atau marah.

Konon ceritanya mamak lagi sensi dan ngambek sama trio kwek kwek.jadi semalaman nggak ngomong apa-apa sama mereka..diem ajaaa..husna loncat-loncat di sofa depan rumah eike diem aja.. Mubarak mainan gunting sampe banyak sampah dikamarnya eike diem aja.aisyah main nggak inget kudu pulang sampai jam 11 malem eike diem aja..mereka rebutan remote eike diem aja..sampe mereka kasak kusuk baru nyadar nggak ada suara growl mamaknya. dan saya tidur duluan nak kanak saya cuekin..rumah amburadul saya cuekin..ngedemin hati tidur.. daripada nyinden ngerap sebab emosi ma nak kanak tak iye..lagian mereka libur Chinese new year..selasa baru sekolah..perlu energi luar biasa selama mereka libur plus budget makanan ekstra..kedengaran sayup sayup mereka diskusi weei mamak marah lah meski sakit hati dengan kita sampai tak nak cakap langsung kata тити.. tu lah sampai kita nakal buat macam-macam pun mamak diem jee mesti teruk sangat mamak sakit hati dengan kite. timpal aisyah..jomlah kemas nanti kite berdosa dengan mamak allah marah kite jadi durhaka..husna nyamber..saya dengernya terharu dan mau ngikik.pagi bangun mau qilamul lail..terharu liat rumah bersih..lantai mengkilat udah disapu pel..piring kotor jadi kinclong..buku disusun..semua rapih.
Kadang cukup diaam aja anak anak malah sadar sendiri takut sendiri paham salahnya dimana..tanpa perlu jerit melengking tinggi (Status tanggal15 Februari 2018)

Mencermati status tersebut, K.W memberi dua pesan. Pertama, cara mendidik anak tanpa emosi. Kedua, mengabarkan respon positif anak-anak terhadap sikap dan perilaku ibu. Mungkin awalnya K.W mendiamkan anak-anak karena emosi dan lelah. Namun, ditengah kondisi itu dia menemukan cara tepat untuk membuat anak-anak sadar, berpikir, dan bertanggung jawab.

Kehidupan sosial anak autis memang unik. Mencermati status-status K.W, tergambar kehidupan sosial yang baik jika orang yang berinteraksi dengan mereka juga baik. Berikut narasi K.W tentang HU yang sempat tidak suka sekolah karena mengalami hal yang tidak membuatnya nyaman.

Belakangan ini saya dibikim tertekan sama husna..yuppp anak bungsu tiap jam berangkat sekolah ngamuk..mogok nggak mau sekolah.dia cerita nggak nyaman sama sekolahnya bukan sebab cikgu bukan sebab bobot pelajaran.tapi sebab temen-temannya sekelas..banyak teman sekelas agak nggak suka sama husna sebab dia rajin angkat tangan. walau nggak ditanya cikgu..walau kadang dia nggak tau jawabannya..selain itu banyak yang usil sama husna dari mulai ngambil alat tulisnya..bahkan pernah dikeroyok hanya karena dianggep nggak mau nge geng..tadi dia ninju temen sekelasnya yang laki-laki karena ngembat milo uht yang bawa dari rumah..awak lai kali kalua nak cakap.jangan ambil macam tu Namanya mencuri...mencuri tak baik tak elok berdosa allha marah..kalau awak cakap elok saya bagi awak munim milo saya..kan kita berkawan..

Anak tadi langsungdia,...kejadinnya diliat sama beberapa pengawas dan guru.satu tau waktu jemput dia di ajak omong sama guru konseling.. saya bawa husna muter muter naik motor tadi..bawa ke took buku beli buku teks bahasas inggris yang dia hilangkan..sepanjang jalan 
coba ngobrol ma dia nanya apa yang bikin dia mogok sekolah..dan males sekolah..sempet saya tawarin pindah sekolah ke sekolah aisyah karena disekolah aisyah banyak mantan teman pra sekolahnya..dia nggak mau karena diasuka semua guru disekolahnya sekarang..saya belum neтu formula ngepas ngadepin masalah husna dan teman classmatenya.. (Status tanggal 8 Februari 2018)

Menarasikan kehidupan sosial anak autis melalui pengalaman bersama MU, status K.W mendeskripsikan bahwa anak autispun mengalami fasefase perkembangan psikologis dan biologis yang sama dengan anak-anak pada umumnya. Seperti dalam relasi MU dengan lawan jenis dalam status berikut:

Ada seorang cewek remaja ternyata umurnya 18 tahun..lagi persiapan utnuk kuliah baru lulus sekolah..dia dating kerumah..ternyata kenal mumu ngabehi..saya bilang mumu nggak ada.dia nanya ke saya apa benar тити itu special needs..saya bilang iya тити special needs dengan diagnose autistic dan adhd juga dyslexia..dia bilang kalo no wonder тити "berbeda" dari banyak cowok yang dia kenal..waktu dia pernah ngajak mumu naik mobilnya muтu milih duduk dibelakang..si cewek ini nanya kenapa nggak mua duduk disebelah dia..mumu dengan lempeng dan jujurnya bilang takut duduk disebelah dia..karena kalua terlalu dekat cewek itu dia merasakan penisnya jadi nggak nyaman.. dan dia nggak mau masturbasi sembarangan..karena sepakat sama saya sebagai mamaknya dia boleh masturbasi dalam keadaan sangat darurat dan Cuma ditempat privacy..si cewek ini kaget sama kejujuran muтu..awalnya dia nyangka si muтu de caprio ini omes alias otak mesum..tapi тumu dibilangin kalau dia autistic..si cewek awalnya nggak percaya.. makanya dia penasaran seminggu stalking mumu termasuk nanya nanya dilingkungan sekolah тити... dan temen mumu nongkrong di cyber café alias warnet.. akhirnya dia ke rumah dan pas ketemu saya.. dia minta ijin mau jadi teman muти.. saya bilang boleh aja nggak masalah.. asal tolong paham mumu ini jangan diajak aneh aneh.dia janji sama saya akan jadi teman yang baik.. si cewek pamitan.ternyata dia nyetir mobil sendiri.. setelah dia pamit saya rasanya kayak ngunyah nano nano sambil naik roller coster denger cerita cewek tadi..anak autistic saya memang sudah remaja..akan makin banyak yang perlu saya bicarakan secara terbuka sama dia (Status tanggal 14 Januari 2018)

\section{KESIMPULAN}

Berdasarkan sajian temuan data maka bisa disimpulkan bahwa K.W membangun narasi pada dua tema besar. Pertama tentang Sifat, watak dan Prinsip anak Autis. Pada tema ini K.W tampak dengan jelas mengonstruksi autism sebagai gangguan perilaku yang khas, dan bukan sebagai kecacatan. Anak autism memiliki prinsip yang terpuji jika sejak mula orang tua, keluarga, dan masyarakat memperkenalkan nilai-nilai yang terpuji. Internalisasi nilai itu akan diterima oleh anak-anak autis dengan sangat patuh, rigid, dan lurus didalam menegakkan nilai-nilai di setiap sendi kehidupan mereka. Bagi penyandang autis, hitam adalah hitam. Putih adalah putih. Oleh karena itu ketika orang -orang sekitar berperilaku beda dengan nilai yang mereka pahami, maka itu akan membuat anak autis bingung dan kecewa, bahkan menimbulkan kegusaran.

Tema besar kedua adalah, narasi tentang prestasi anak autis. K.W mengonstruksi sebagai prestasi yang tidak ada perbedaan dengan anak-anak tipikal. Ketika anak autis telah menemukan passion, maka mereka hanya ingin dimengerti dan memerlukan dukungan melalui pengarahan, bimbingan, dan diberi kepercayaan. Anak autis merasa tertekan ketika mereka merasa orang tua tidak bangga dengan apa yang menjadi passion mereka. Anak autis yang telah remaja seperti MU bahkan merasa bersyukur dan terselamatkan sebagai penyandang autism. Oleh karena itu menuntut anak autis bisa segalanya yang bersifat general, sama hanya merusak kepercayaan diri mereka dan menimbulkan frustasi

Peneliti merekomendasikan dilakukan penelitian 
lanjutan dengan subjek para penyandang autism sendiri yang sudah mampu menyampaikan pengalamannya secara verbal, baik secara lisan dan ataupun tertulis. Promosi tentang "dunia kehidupan" para penyandang autism perlu dilakukan terus menerus dengan berbagai media dan metode sehingga masyarakat benar-benar bisa melihat autism sebagai kelompok sosial, bukan sebagai perbedaan ataupun kecacatan.

\section{DAFTAR PUSTAKA}

Andrews, Molly. Squire, Corrine. Tamboukou, Maria. 2008. Doing Narrative Research. London: Sage Publication.

Conti, Marco. Dunbar, Robin. 2015. Online Social Network. Amsterdam: Elseiver

Dwyer, Rachel. 2017. Narrative Research in Practice: Stories from the Field. Singapore: Springer.

Frost, Nollaig. 2011. Qualitative Research in Psychology: Combining Core Approach. New York: McGraw Hill.

Kin, Diane. Dockrell, Julie. Stuart, Morag. (2014). Constructing fictional stories: A study of story narratives by children with autistic spectrum disorder Research in Developmental Disabilities 35(10):24382449. June 2014.

Kusumastuti, Frida. (2018). Tindakan Komunikatif Orang Tua dalam Penanganan Anak Penyandang Autism. Disertasi. Pascasarjana Universitas Muhammadiyah Malang.

Lázaro, P. Cristiane and Pondé, P. Milena. (2017). Narratives of mothers of children with autism spectrum disorders: focus on eating behavior. Trends Psychiatry Psychother. vol.39 no.3 Porto Alegre July/Sept. 2017

Lister, Martin, et all. (2003). New Media: A Critical Introduction, 2nd Edition. New York: Routledge.

McCarthy, E. Doyle. 1996. Knowledge as Culture. London: Routledge.

Randall, P., and J. Parker. 1999. Supporting the families of children with autism. Chichester, UK: Wiley.

Rogers LG, Magill-Evans J, Rempel GR. Mothers.
Challenges in feeding their children with autism spectrum disorder - managing more than just picky eating. J Dev Phys Disabil. 2012; 24: 19-33.

Tedlock, Barbara. 2011. Observasi Partisipan dan Kemunculan Etnografi Publik dalam Handbook of Qualitative Research 1 (terjemahan Third Edition). Yogjakarta. Pustaka Pelajar.

Syaibani, Yunus Ahmad, dkk. (2011). New Media: Teori dan Aplikasi. Karanganyar, Jawa Tengah: Lindu Pustaka

A. Susilo, (2017). "Memahami Komunikasi Penyesuaian Diri Anak Tunarungi Di Sekolah Inklusi, "Interaksi: Jurnal Ilmu Komunikasi, vol. 6, no. 2, pp. 110, Jul. 2017. https://doi.org/10.14710/interaksi.6.2.110

Asdewiyah, Rofiana dan Kusumastuti, Frida. 2014. Membangun Keluarga "Ramah Autisma” melalui Tindakan Komunikatif Ibu dari Anak Penyandang Autisma. Procedding; http://repo.uum.edu.my/13096/

Astri Nur Kusumastuti, 2014, Stress ibu Tunggal yang Memiliki Anak Autis, Jurnal Psikologi Volume 2 No. 7 Desember 2014, halaman 54-61

Block, Betty Ann \& Weatherford, Gwendolyn M. (2013). Narrative Research Methodologies: Learning Lessons from Disabilities Research. Quest. 65:4. $498: 51$

M. Mubarok. (2912). "Stigmatisasi Pemberitaan Terorisme di Media Massa," Interaksi: Jurnal Ilmu Komunikasi, vol. 1, no. 1, pp. 34-45, Jul.2012.

https://doi.org/10.14710/interaksi.1.1.34-45 Gockel, A. 2013. Telling the Ultimate Tale: The Merits of Narrative Research in the Psychology of Religion. Qualitative Research in Psychology, 10(2), 189-203.

Good, Day Katie. From scrapbook to Facebook: A history of personal media assemblage and archives. New Media and Society 15 (4). 2012. nms.sagepub.com Lambert, Alex. Intimacy and social capital on Facebook: Beyond the psychological perspective. New Media and Society 1-17. 2015. nms.sagepub.com

Diagnostic Statistical Manual for Mental Disorders V. 2013. American Psychiatric Association. 
Wiguna, Tjhin Wiguna, SpKJ(K). (2015). Apa yang perlu anda ketahui tentang Gangguan Spektrum Autisme? https://www.otsuka.co.id/id/healthtinfo/detail/5/ apa\%20yang\%20 